\title{
SYNTHESIS OF HYDROXYL TERMINATED LIQUID NATURAL RUBBER BY OXIDATIVE DEPOLYMERIZATION OF DEPROTEINIZED NATURAL RUBBER
}

\author{
Le Duc Giang*, Dinh Mong Thao, Hoang Thi Huong, Le Thi Thu Hiep \\ Faculty of Chemistry, Vinh University, 182 Le Duan, Vinh City \\ "Email: Leducgiang@gmail.com
}

Received: 6 October 2015; Accepted for publication: 21 December 2015

\begin{abstract}
Hydroxyl terminated liquid natural rubber (HTLNR) was prepared by the depolymerization of deproteinized natural rubber (DPNR) in mixture of toluene and water at $60{ }^{\circ} \mathrm{C}$ for 24 hours in the presence of ammonium persulfate as an initiator and tetrahydrofuran (THF) as a homogenizing agent. GPC analysis revealed that the number-average molecular weight $\left(M_{n}\right)$ and weight-average molecular weight $\left(\mathrm{M}_{\mathrm{w}}\right)$ of HTLNR were found to be $4.334 \times 10^{3} \mathrm{~g} / \mathrm{mol}$ and $11.702 \times 10^{3} \mathrm{~g} / \mathrm{mol}$, respectively, with polydispersity index (PDI) of 2.7 . The chemical structure of HTLNR was determined by FTIR and ${ }^{1} \mathrm{H}-\mathrm{NMR}$ and ${ }^{13} \mathrm{C}-\mathrm{NMR}$ spectroscopic analysis. Based on the analytical data the mechanism of depolymerization and hydroxylation of NR to form HTNR was also suggested.
\end{abstract}

Keywords: deproteinized natural rubber (DPNR), hydroxyl terminated liquid natural rubber (HTLNR), depolymerization of natural rubber, oxidative degradation.

\section{INTRODUCTION}

Liquid natural rubber (LNR) is a modified form of natural rubber (NR) with shorter polymeric chains. LNR has some benefits for making adhesives, coatings and sealants. It is also used for various rubber goods other than tires, for example, anti-vibration rubber, fender, conveyer belt for mining, rubber hose and so on. Especially, the LNR with terminated functional groups are very useful for use as intermediates, for example, reactive compatibilizers plastisizers, modifiers as well as in chain extension and grafting reactions [1 - 3].

There are some main methods that are used to make LNR such as depolymerization of NR by thermal, mechanical, oxidative and photochemical degradations. However, oxidative and photochemical methods can give LNR with reactive terminated functional groups [1].

Various degradation reagents such as phenylhydrazine-ferrous chloride [4], phenylhydrazine-atmospheric oxygen, periodic acid [5], potassium persulfate and propanal [6] as well as ozone [7] had been used in the preparation of LNR and epoxidized LNR in latex state. Ravindran and coworkers [2] reported the production of HTLNR by photochemical 
depolymerization of NR toluene solution at room temperature in the presence of $\mathrm{H}_{2} \mathrm{O}_{2}$ and homogenizing agents such as methanol and THF. Bac et al. [8] used hydrogen peroxide and sodium nitrite in the presence of formic acid to produce liquid epoxidized natural rubber (LENR). Recently, H.L. Pham et al. [9] synthesized HTLNR by using photo-Fenton reaction and Suhawati Ibrahim et al. [10] used hydrogen peroxide and sodium nitrite in the presence of formic acid to produce LNR.

In this paper, we report some results that concern the preparation of HTNR by using ammonium persulfate as an initiator to depolymerize NR, the characterization of the HTNR is obtained by GPC, FTIR, ${ }^{1} \mathrm{H}-\mathrm{NMR}$ and ${ }^{13} \mathrm{C}$-NMR spectroscopic analysis. The mechanism of depolymerization and hydroxylation of NR to form HTNR based on the analytical data is also discussed in this study.

\section{EXPERIMENTS AND METHODS}

\subsection{Materials}

High ammonia stabilized natural rubber latex containing about $30 \%$ of dry rubber content $\left(M_{\mathrm{n}} \sim 7.8 \times 10^{6} \mathrm{~g} / \mathrm{mol}, \mathrm{pH} \sim 9.8\right)$ was provided by the Dong Duong Group (Vietnam).

Toluene, methanol, tetrahydrofuran (THF), sodium dodecyl sulfate (SDS; $99 \%$ ), were purchased from Sigma-Aldrich (USA), hydroquinone, ammonium persulfate were purchased from Merck (Germany), Urea (99.5\%) was purchased from Loba Chemie (India). All other chemicals and solvents were of purest grade commercially available and used without further purification.

\subsection{Preparation of deproteinized natural rubber and HTLNR}

Deproteinized natural rubber (DPNR) was prepared by incubation of the latex with $0.2 \mathrm{wt} \%$ urea and $1 \mathrm{wt} \%$ SDS at a reaction temperature of $30{ }^{\circ} \mathrm{C}$ for $60 \mathrm{~min}$ according to the work of Kawahara et al. [11]. The crumb rubber was recovered by centrifugation followed by coagulation with methanol and dried to a constant weight in a vacuum oven.

$5.0 \mathrm{~g}$ of crumb rubber was dissolved in $100 \mathrm{ml}$ of toluene for 5 days. This solution was charged in a reactor, a round bottom three-neck flask of $250 \mathrm{ml}$ capacity equipped with a water condenser, a magnetic stirrer and a water bath. After that, $20 \mathrm{ml}$ borate buffer solution $(\mathrm{pH}=9)$, $20 \mathrm{ml}$ THF and 0,1g ammonium persulfate were introduced into the flask. The mixture was stirred and heated to $60{ }^{\circ} \mathrm{C}$ for 24 hours. After 24 hours reaction, hydroquinon solution $(0.5 \mathrm{wt} \%$, $2 \mathrm{~mL}$ ) was dispersed in the solution and was allowed to stand for a certain time. A layer of water separated at the bottom along with some white deposits as byproduct. This was removed, and the liquid rubber was recovered from the top toluene layer by distilling of the solvent under low pressure. Finally, the product was purified by repeated precipitation by methanol from a toluene solution and washed with distilled water to $\mathrm{pH}=7$ then dried at $70{ }^{\circ} \mathrm{C}$ in a vacuum oven.

\subsection{Characterization methods}

The chemical structure of the HTLNR was examined by FTIR spectroscopy using a Shimadzu Irprestige-21 spectrometer at Faculty of Chemistry, Hanoi National University of Education; ${ }^{1} \mathrm{H}-\mathrm{NMR}$ and ${ }^{13} \mathrm{C}-\mathrm{NMR}$ spectra using $\mathrm{CDCl}_{3}$ as solvent and TMS as internal standard were recorded on the NMR spectrometers ADVANCE $125 \mathrm{MHz}$ and ADVANCE $500 \mathrm{MHz}$ of 
Bruker at Institute of Chemistry-Vietnam Academy of Science and Technology, respectively.

The number average molecular weight, weight average molecular weight and polydispersity index (PDI) were measured by gel permeation chromatography (GPC) with differential refractometer RID-10A (Shimadzu, Japan) at Faculty of Chemistry, University of Science, VNU-Hanoi. All measurements were carried out at $30{ }^{\circ} \mathrm{C}$ using THF as solvent with flow rate of $1.0 \mathrm{~mL} / \mathrm{min}$. The system was calibrated using polystyrene standards with the molecular weight range from $2.95 \times 10^{3} \mathrm{~g} / \mathrm{mol}$ to $4.22 \times 10^{4} \mathrm{~g} / \mathrm{mol}$.

\section{RESULTS AND DISCUSSION}

\subsection{Chemical structure of the HTLNR}

The FTIR spectrum of HTLNR is shown in Fig.1. Those bands characteristic of cis-1,4isopren, as found in the NR, are also found in HTLNR, such as: C-H bending at $2920 \mathrm{~cm}^{-1}, \mathrm{C}-\mathrm{H}$ stretching at $1446 \mathrm{~cm}^{-1}$; the important characteristic bands for NR appear at 1662 and $833 \mathrm{~cm}^{-1}$, which are assigned to the $\mathrm{C}=\mathrm{C}(\mathrm{cis})$ stretching and $=\mathrm{C}-\mathrm{H}$ deformation stretching, respectively. Apart from the major absorption bands characteristic for $\mathrm{cis}$-1,4-isoprene, other absorption bands were also observed in the FTIR spectrum of HTNR such as a broad absorption band at 3200$3500 \mathrm{~cm}^{-1}$, characteristic of $\mathrm{OH}$ stretching vibration; an absorption band at $1373 \mathrm{~cm}^{-1}$ of $\mathrm{C}-\mathrm{O}$ stretching, that confirmed the presence of primary hydroxyl groups in the depolymerized product.

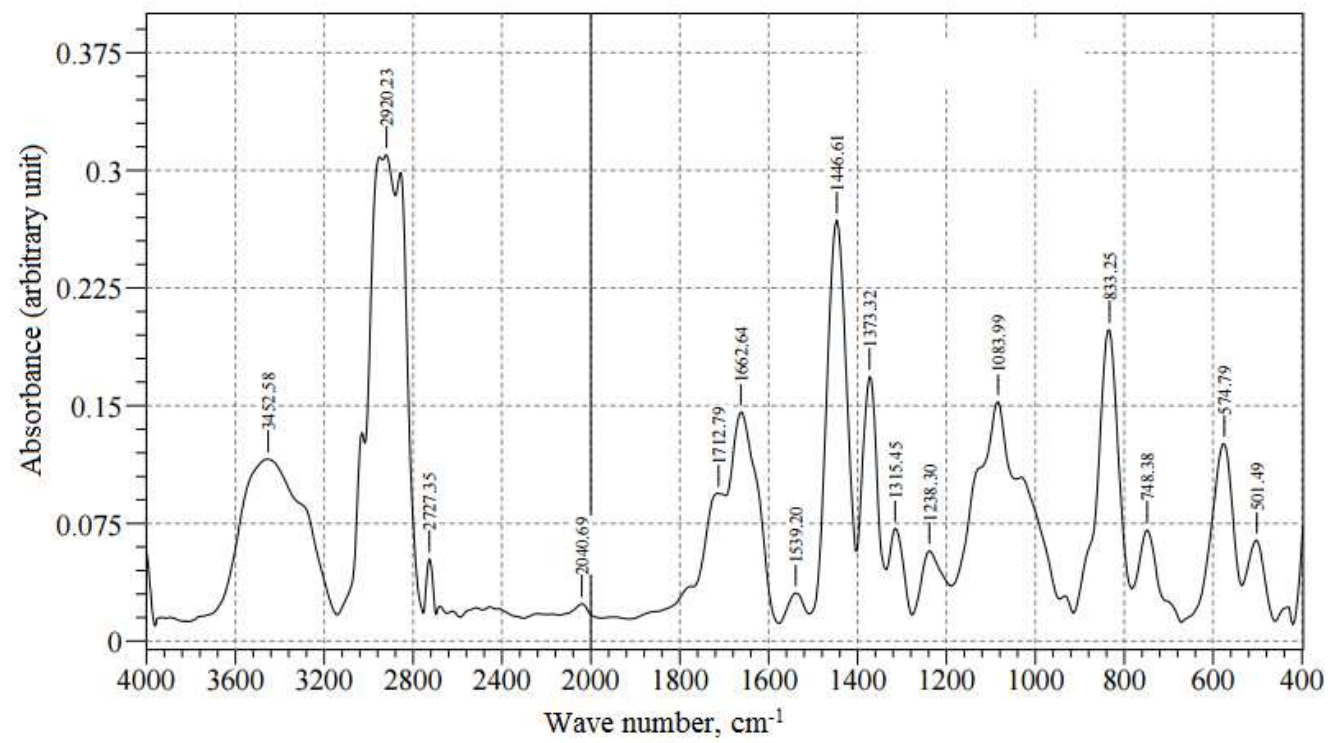

Figure 1. FTIR spectrum of HTLNR.

Figure 2 shows the proton peaks of NR at $\delta=1.65,2.05$ and $5.12 \mathrm{ppm}$ which are assigned to the methyl $(s, 3 \mathrm{H})$, methylene $(\mathrm{brs}, 4 \mathrm{H})$ and unsaturated methine $(m, 1 \mathrm{H})$ protons, respectively. The signal due to the hydroxyl proton in the hydroxymethyl group is usually observed around $\square=4.0 \mathrm{ppm}$ to $4.2 \mathrm{ppm}$. This however, could not be detected in the present case, since the signal/noise ratio was too unfavorable to see the end groups. 

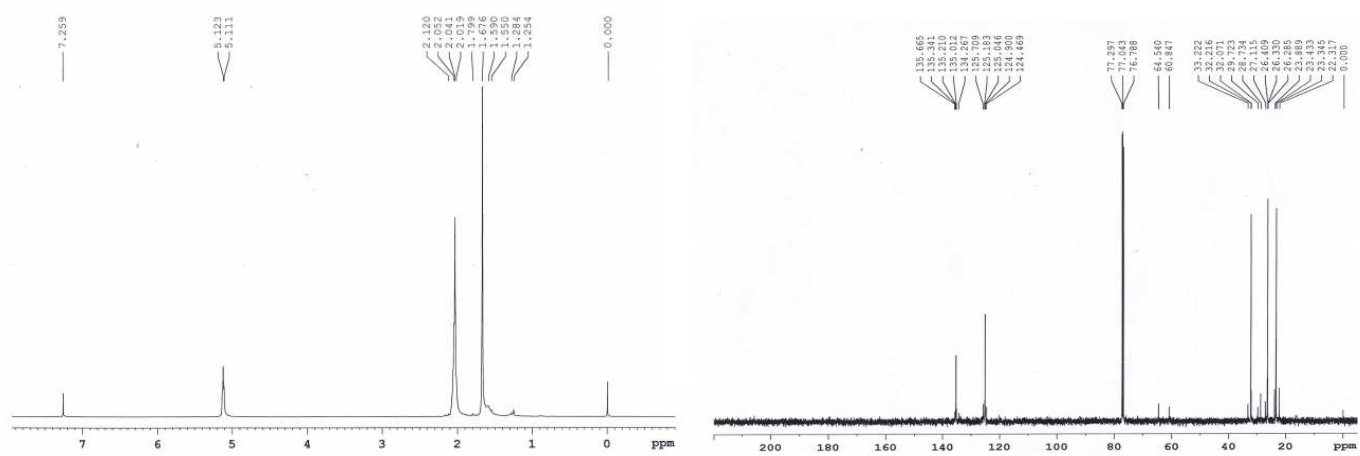

Figure 2. ${ }^{1} \mathrm{H}-\mathrm{NMR}$ spectrum of HTLNR. Figure $3 .{ }^{13} \mathrm{C}-\mathrm{NMR}$ spectrum of HTLNR.

The ${ }^{13} \mathrm{C}$-NMR spectrum is shown in Figure 3 which includes characteristic peaks of 5 cacbon atoms on NR: $\mathrm{C}_{1}(32.22 \mathrm{ppm}), \mathrm{C}_{2}(134.23 \mathrm{ppm}), \mathrm{C}_{3}(124.45 \mathrm{ppm}), \mathrm{C}_{4}(26.34 \mathrm{ppm}), \mathrm{C}_{5}$ $(23.34 \mathrm{ppm})$. Apart from these major peaks the spectrum also contained minor peaks at $\mathrm{d}=78.39$, 76.98 and $75.57 \mathrm{ppm}$ due to $\mathrm{CDCl}_{3}$. Other minor peaks at $\delta=60.85$ and $64.54 \mathrm{ppm}$ could be due to $\alpha$-carbons attached to the hydroxyl groups in structures like (I) and (II), respectively and hence could indeed correspond to an $\alpha$-hydroxymethyl group.<smiles>CC(C)=CCO</smiles>

(I)<smiles>CC=C(C)CO</smiles>

(II)

Several minor peaks could also be observed at $\delta$ from 22.32 to $33.22 \mathrm{ppm}$ in the ${ }^{13} \mathrm{C}-\mathrm{NMR}$ spectrum of HTNR (Figure 3), indicating the probable side products due to the formation of epoxy group.

The broad $\mathrm{OH}$ stretching band at $3200-3500 \mathrm{~cm}^{-1}$ in the FTIR spectrum of the HTNR (Figure 1) and also the peaks at $\delta=60.85 \mathrm{ppm}$ and $64.54 \mathrm{ppm}$ (Figure 3) which were characteristic of the $\alpha$-carbons of allylalcohol in the ${ }^{13} \mathrm{C}$-NMR spectrum of HTNR suggest the terminal hydroxyl groups in the product. The allylic hydroxyl protons in the ${ }^{1} \mathrm{H}-\mathrm{NMR}$ spectrum were masked by the multiples at $\delta=5.12 \mathrm{ppm}$ of the $>\mathrm{C}=\mathrm{C}-\mathrm{H}$ protons.

\subsection{Molecular weight of HTLNR}

GPC analysis revealed that the number-average molecular weight $\left(\mathrm{M}_{\mathrm{n}}\right)$ and weight-average molecular weight $\left(\mathrm{M}_{\mathrm{w}}\right)$ of HTLNR were found to be $4.334 \times 10^{3} \mathrm{~g} / \mathrm{mol}$ and $11.702 \times 10^{3} \mathrm{~g} / \mathrm{mol}$, respectively, with polydispersity index (PDI) of 2.7 (Table 3.1).

Table 3.1. The number-average molecular weight $\left(\mathrm{M}_{\mathrm{n}}\right)$ and weight-average molecular weight $\left(\mathrm{M}_{\mathrm{w}}\right)$ of HTLNR.

\begin{tabular}{|c|c|c|}
\hline $\begin{array}{c}\text { Number-average molecular } \\
\text { weight }(\mathrm{g} / \mathrm{mol})\end{array}$ & $\begin{array}{c}\text { Weight-average molecular } \\
\text { weight }(\mathrm{g} / \mathrm{mol})\end{array}$ & $\begin{array}{c}\text { Polydispersity index } \\
\text { (PDI) }\end{array}$ \\
\hline $4.334 \times 10^{3}$ & $11.702 \times 10^{3}$ & 2.7 \\
\hline
\end{tabular}




\subsection{Mechanism of depolymerization and hydroxylation}

In all the earlier proposals free radical mechanism has been suggested for the degradation of NR. The chemical reagents used in the process are free radical generators such as thiols, peroxides, Fenton reagent, photo-Fenton reagent, etc. [1,9]. In the NR, the $\sigma$ bond between $\alpha-$ methylenic groups which connect the isoprene units are not in the same plane with the double bonds. This is because there is a tendency of coiling up of the rubber segments due to its cis configuration.<smiles>CC/C=C(\C)CC/C=C(\C)CC</smiles>

Structure of natural rubber

The steric hinderance caused by such an unbalanced structure with pendent methyl groups weakens the $\mathrm{CH}_{2}-\mathrm{CH}_{2}$ bond, leading to its rupture under favorable conditions which are provided by thermal energy or the chain modifications caused by radical species or by radiation [2].

Persulfate salts are dissociated in water to the persulfate anion (equation 1) which, despite having a strong oxidation potential $\left(\mathrm{E}^{\mathrm{o}}=2.01 \mathrm{~V}\right)$, is kinetically slow to react with many organic compounds. Studies have indicated that persulfate anions can be activated to generate sulfate radicals $\left(\mathrm{SO}^{\circ}\right)$, which are stronger oxidants compared to the persulfate anion $(\mathrm{Eo}=2.6 \mathrm{~V})$. The most common approach to activate the generation of sulfate radicals is the use of base. Recent studies have demonstrated the influence of $\mathrm{pH}$ on the generation of reactive oxygen species in base-activated persulfate systems. Under these conditions most sulfate radicals are converted to hydroxyl radicals (equation 2) [12, 13].

Based on the above discussion, the following mechanism is suggested for the depolymerization and hydroxylation of NR $[2,9,12]$ (Scheme 1):

$$
\begin{aligned}
& \mathrm{S}_{2} \mathrm{O}_{8}{ }^{2-} \stackrel{\mathrm{t}^{\mathrm{O}}}{\longrightarrow} 2 \mathrm{SO}_{4}^{--} \\
& \mathrm{SO}_{4}^{-{ }^{-}}+\mathrm{OH}^{-} \longrightarrow \mathrm{SO}_{4}{ }^{2-}+\mathrm{OH}^{-}
\end{aligned}
$$

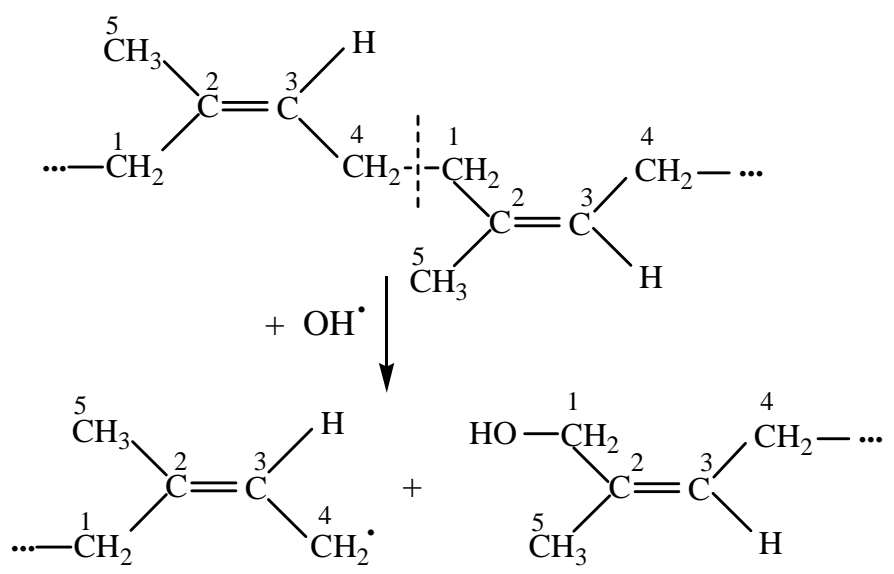




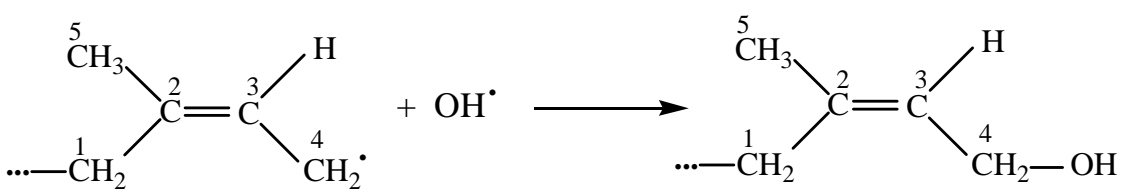

Scheme 1. Proposed mechanism for depolymerization and hydroxylation of NR.

\section{CONCLUSION}

HTNLR $\left(\mathrm{M}_{\mathrm{n}} \sim 4.334 \times 10^{3} \mathrm{~g} / \mathrm{mol}, \mathrm{M}_{\mathrm{w}} \sim 11.702 \times 10^{3} \mathrm{~g} / \mathrm{mol}\right.$ and PDI $\left.\sim 2.7\right)$ was successfully prepared by the depolymerization of NR in toluene solution using tetrahydrofuran (THF) as a homogenizing agent and ammonium persulfate as an initiator at $60{ }^{\circ} \mathrm{C}$ for 24 hours. Chemical structure of HTLNR was examined by FTIR and ${ }^{1} \mathrm{H}-\mathrm{NMR},{ }^{13} \mathrm{C}-\mathrm{NMR}$ spectroscopic analysis. The obtained data confirmed the occurence of the oxidative degradation reaction to yield LNR with hydroxyl terminated groups. The mechanism of depolymerization and hydroxylation of NR to form HTNR based on the analytical data is also suggested in this study.

\section{REFERENCES}

1. Nor H. M., Ebdon J. R. - Telechelic liquid natural rubber: A review, Prog. Polym. Sci. 23 (1998) 143-177.

2. Ravindran T., Nayar M. R. G., Francis D. J. - Production of hydroxyl-terminated liquid natural rubber-Mechanism of photochemical depolymerization and hydroxylation, $\mathrm{J}$. Appl. Polym. Sci. 35 (1988) 1227-1239.

3. Zainol I., Ahmad M. I., Zakaria F. A., Ramli A., Marzuki H. F. A., Aziz A. A. Modification of epoxy resin using liquid natural rubber, Mater. Sci. Forum 517 (2006) 272-274.

4. Huy H. T., Nga N. T., Hong L. Q., Chu P. N. S. - Depolymerization of natural rubber latex using phenylhydrazine- $\mathrm{FeCl}_{2}$ system, Pure Appl. Chem. 33 (1996) 1923-1930.

5. Phinyocheep P., Phetphaisit C. W., Derouet D., Campistron I., Brosse J. C. - Chemical degradation of epoxidized natural rubber using periodic acid: Preparation of epoxidized liquid natural rubber, J. Appl. Polym. Sci. 95 (2005) 6-15.

6. Chaikumpollert O., Sae-Heng K., Wakisaka O., Mase A., Yamamoto Y., Kawahara S. Low temperature degradation and characterization of natural rubber, Polym. Degrad. Stab., 96 (2011) 1989-1995.

7. Kodama S., Nishi K., Furukawa M. - Preparation of low molecular weight natural rubber by ozonolysis of high ammonia latex, J. Rubb. Res. 6 (2003) 153-163.

8. Bac N. V., Terlemezyan L., Mihailov M. - Epoxidation of natural rubber in latex in the presence of a reducing agent, J. Appl. Polym. Sci. 50 (1993) 845-849.

9. Pham H. L., Do B. T., Pham T. S., Le D. G. - Synthesis and characterisation of hydroxylterminated liquid natural rubber by photo-Fenton reaction, ASEAN J. Sci. Technol. Dev. 30 (2013) 29-36.

10. Suhawati I., Rusli D., and Ibrahim A. - Functionalization of liquid natural rubber via oxidative degradation of natural rubber, Polymers 6 (2014) 2928-2941. 
11. Kawahara S, Klinklai W., Kuroda H, Isono Y. - Removal of proteins from natural rubber with urea, Polym Adv Technol. 15 (2004) 181-184.

12. House D. A. - Kinetics and mechanism of oxidation by peroxydisulfate, Chem. Rev. 62 (1962) 185-200.

13. Liang C., Wang Z., Bruell C. - Influence of $\mathrm{pH}$ on persulfate oxidation of TCE at ambient temperatures, Chemosphere 66 (2007) 06-113.

\title{
TÓM TẮT
}

\section{TỔNG HỢP CAO SU THIÊN NHIÊN LỎNG CÓ NHÓM HYDROXYL CUỐI MACH BẰNG PHƯƠNG PHÁP CẮT MẠCH OXI HÓA CAO SU THIÊN NHIÊN DEPROTEIN HÓA}

\author{
Lê Đức Giang ${ }^{*}$, Đinh Mộng Thảo, Hoàng Thị Hướng, Lê Thị Thu Hiệp
}

Khoa Hóa học, Đại học Vinh, 182 Lê Duẩn, Tp. Vinh

"Email: Leducgiang@gmail.com

Cao su thiên nhiên lỏng có nhóm hydroxyl cuối mạch (HTLNR) đã được điều chế bằng phản ứng cắt mạch oxi hóa cao su thiên nhiên deprotein hóa trong hỗn hợp toluen và nước ở $60{ }^{\circ} \mathrm{C}$ trong 24 giờ, chất đồng thể tetrahidrofuran (THF) và chất khơi mào amoni persunfat. Phương pháp sắc kí thẩm thấu gel (GPC) đã xác định được khối lượng phân tử trung bình số, khối lượng phân tử trung bình khối và độ phân bố khối lượng phân tử của HTLNR lần lượt là $4,334 \times 10^{3} \mathrm{~g} / \mathrm{mol}, 11,702 \times 10^{3} \mathrm{~g} / \mathrm{mol}$ và 2,7 . Cấu trúc hóa học của HTLNR được khẳng định bằng phương pháp phô̂ hồng ngoại và cộng hưởng từ hạt nhân ${ }^{1} \mathrm{H}$ và ${ }^{13} \mathrm{C}$. Trong công trình này chúng tôi cũng đã đề xuất cơ chế phản ứng cắt mạch và hydroxyl hóa cao su thiên nhiên tạo thành HTLNR trên cơ sở phân tích các dữ liệu và các công trình đã công bố.

Tư khóa: cao su thiên nhiên deprotein hóa, cao su thiên nhiên lỏng có nhóm hydroxyl cuối mạch, cắt mạch oxi hóa cao su thiên nhiên, phân hủy oxy hóa. 